\title{
Geological setting of the Chandragiri-Chitlang Range, southwest of Kathmandu Valley, central Nepal
}

\author{
*Manjari Acharya and Kabi Raj Paudyal \\ Central Department of Geology, Tribhuvan University, Kirtipur, Kathmandu, Nepal \\ *Corresponding author: acharyal1.manjari@gmail.com
}

\begin{abstract}
Geological mapping was carried out in the scale of 1:25000 in the Chandragiri-Chitlang Range of central Nepal, SW of the Kathmandu Valley. In the area, lower four formations of the Phulchoki Group (Paleozoic age) from older to younger sequence, i.e. the Tistung Formation, the Sopyang Formation, the Chandragiri Limestone and the Chitlang Formation along with the Alluvial Fan Deposits and the Kathmandu valley sediments were mapped. Low-grade metamorphic rocks like metasandstone, phyllite, argillaceous limestone, ortho-quartzite and slate dominate the study area. The whole succession of the area is calcareous. The succession consists of a biotite zone in the lower part of the Tistung Formation, whereas the overlying younger succession belongs to a chlorite zone. The Chitlang Formation lies at the core of the Mahabharat Synclinorium and other local-scale structures in the area are the Chitlang Syncline, the Kirtipur Anticline and the Chandragiri Thrust (CT). The repetition of the older Sopyang Formation around the southeastern area and the Tistung Formation around northwestern area over the younger Chandragiri Limestone justifies the presence of the Chandragiri Thrust (CT).
\end{abstract}

Keywords: Chitlang Syncline, Chandragiri Thrust, Kirtipur Anticline

Paper Received: 8 Jan 2019

Paper Accepted: 15 May 2019

\section{INTRODUCTION}

The study area lies in between N $27^{\circ} 35^{\prime} 00^{\prime \prime}$ to $27^{\circ} 43^{\prime} 30^{\prime \prime}$ $\mathrm{N}$ latitudes and $85^{\circ} 09^{\prime} 30^{\prime \prime}$ to $85^{\circ} 19^{\prime} 00^{\prime \prime} \mathrm{E}$ longitudes in the Chandragiri-Chitlang section in the southwestern hills of the Kathmandu Valley (Fig. 1). Few related works have been done by different geoscientists (Hagen 1969; Arita et al. 1973; Stöcklin and Bhattarai 1977; Stöcklin 1980; Sakai 2001; Asahi 2003; Paudyal and Dhital 2005; Sakai et al. 2006; and Acharya and Dhital 2006). Sakai (2001) and Sakai et al. (2006) reported the Chandragiri Fault in the area. Sakai (2006) recognized the Thankot Active Fault coincides with the Chandragiri Fault near its eastern end (Saijo et al. 1995). The present study aimed to identify continuation of the Chandragiri Thrust (CT) in the area. Geological mapping aid with study of metamorphism, microstructure and structural analyses were carried out to map the bedrock units of the area

\section{STRATIGRAPHY}

The Chandragiri-Chitlang section in the area is covered by the rocks of the Phulchoki Group (Stöcklin and Bhattarai 1977; Stöcklin 1980) of Paleozoic age of the Kathmandu Complex. The detailed generalized columnar section (Fig. 2), geological map (Fig. 3) and geological cross-section (Fig. 4 and 5) show the present findings of study.

The stratigraphic units proposed by Stöcklin and Bhattarai (1977) was adopted. Four formations; the Tistung Formation, the Sopyang Formation, the Chandragiri Limestone and the
Chitlang Formation respectively from the older to the younger units of the Phulchauki Group were mapped. Alluvial fans and Kathmandu Valley sediments (Quaternary deposits) cover some part of the area.

The Tistung Formation (Fig. 6), which has Late Cambrian to very Early Ordovician age (Mitchell. 1981) is the oldest unit of the area, where the rock succession dominantly consists of intercalation of grey to brown, massive to thick bedded, laminated metasandstone and dark grey to ash grey, thinly bedded, pelitic

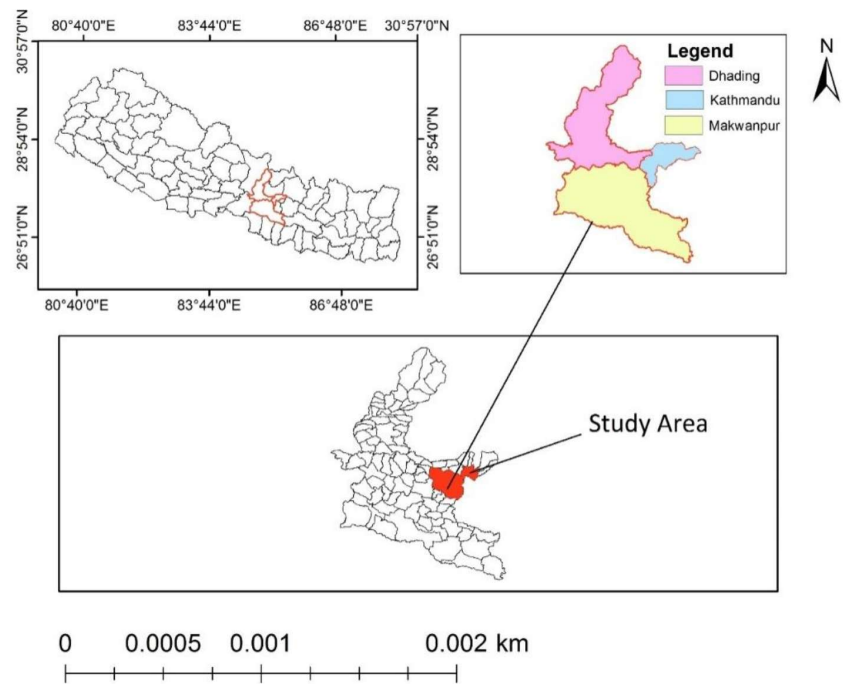

Fig. 1: Location map of the study area 


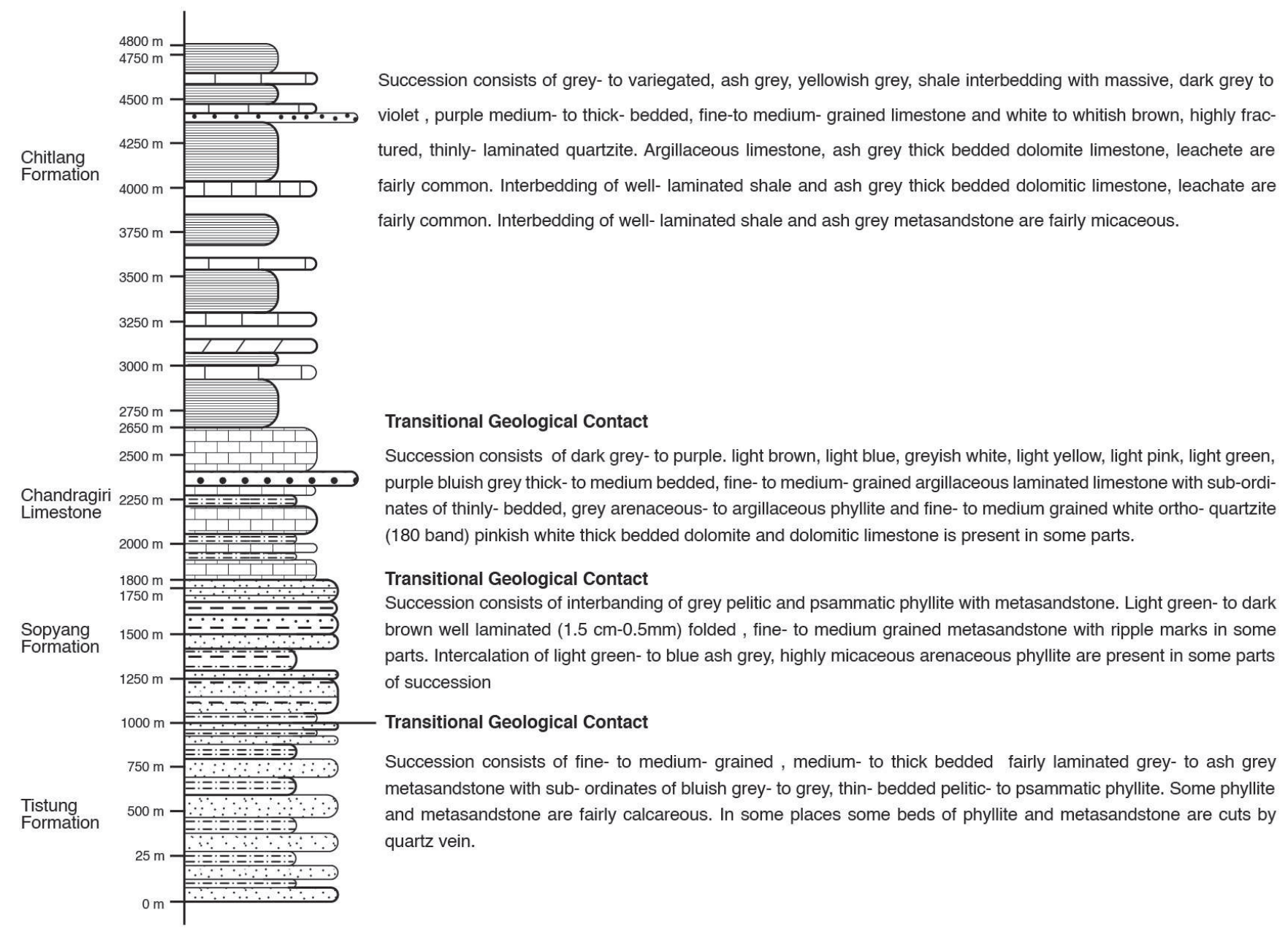

Fig. 2: A generalized columnar section of rocks developed in southern part of the Chitlang Bhanjyang

and psammatic phyllite. Very fine biotite is seen only in the lower part of the succession. Calcareous metasiltstone and metasandstone were frequently observed. Frequent quartz veins cut the micaceous rock beds from different directions.

The Sopyang Formation is a transitional zone between the Tistung Formation and the thick Chandragiri Limestone. The main lithology of this succession is compositional layering of dark grey, fine-grained, pelitic phyllite and grey, coarsegrained metasandstone (Fig. 7). Interbanding of grey, psammatic, coarse-grained and dark grey, pelitic fine-grained metasandstone is mostly observed in the lower part of the succession. At Chobhar, thickness of the succession is only of about $11 \mathrm{~m}$ (Fig. 8). Calcareous metasandstone and light grey, pink siliceous limestone are fairly common in some parts.

The Chandragiri Limestone (Auden, 1935) of Middle Cambrian age (Gupta and Termier, 1978) consists of grey, thin to thick bedded argillaceous, laminated limestone with minor amount of white, ortho-quartzite, light grey with orange weathered argillaceous phyllite and greyish, micaceous metasandstone (Fig. 9). The upper part of the succession comprises of partings of dark grey to light grey phyllite subordinated with white quartzite (about $150 \mathrm{~m}$ ) band and greyish leachate on limestone. The Elephant-skin type weathering on limestone is observed in some parts. The vugs, caves, quartz veins and calcite veins are fairly common in various regions.

The Chitlang Formation of Silurian age (Bordet et al., 1959) was named from the village of Chitlang in the upper Chitlang Valley after Hagen (1969). This formation is distributed in the core of the Mahabharat Synclinorium (i.e., the Chitlang Syncline). It consists mainly of white quartzite, some beds of argillaceous limestone, dark bluish grey, violet shale, slate and dolomitic limestone (Fig. 10). The lower part of this unit consists of violet, shale and slate, white, muddy quartzite, grey, fine-to coarse grained metasandstone, thick-to massive, fine-to mediumgrained limestone and phyllite in some parts. Similarly, upper part of the succession comprises of intercalation between yellowish grey shale and dark grey limestone minorly of dolomite with precipitated calcite in which wave marks are observed.

A large alluvial fan comprised of sands, silts, clay, boulders, cobbles and pebbles are well distributed. In some parts of the area, grey to dark silty clay, clayey silt, dark black organic calcareous clay, clayey to silty sand, poorly graded, and subrounded to rounded gravel are observed in the Kathmandu Valley Sediments. 

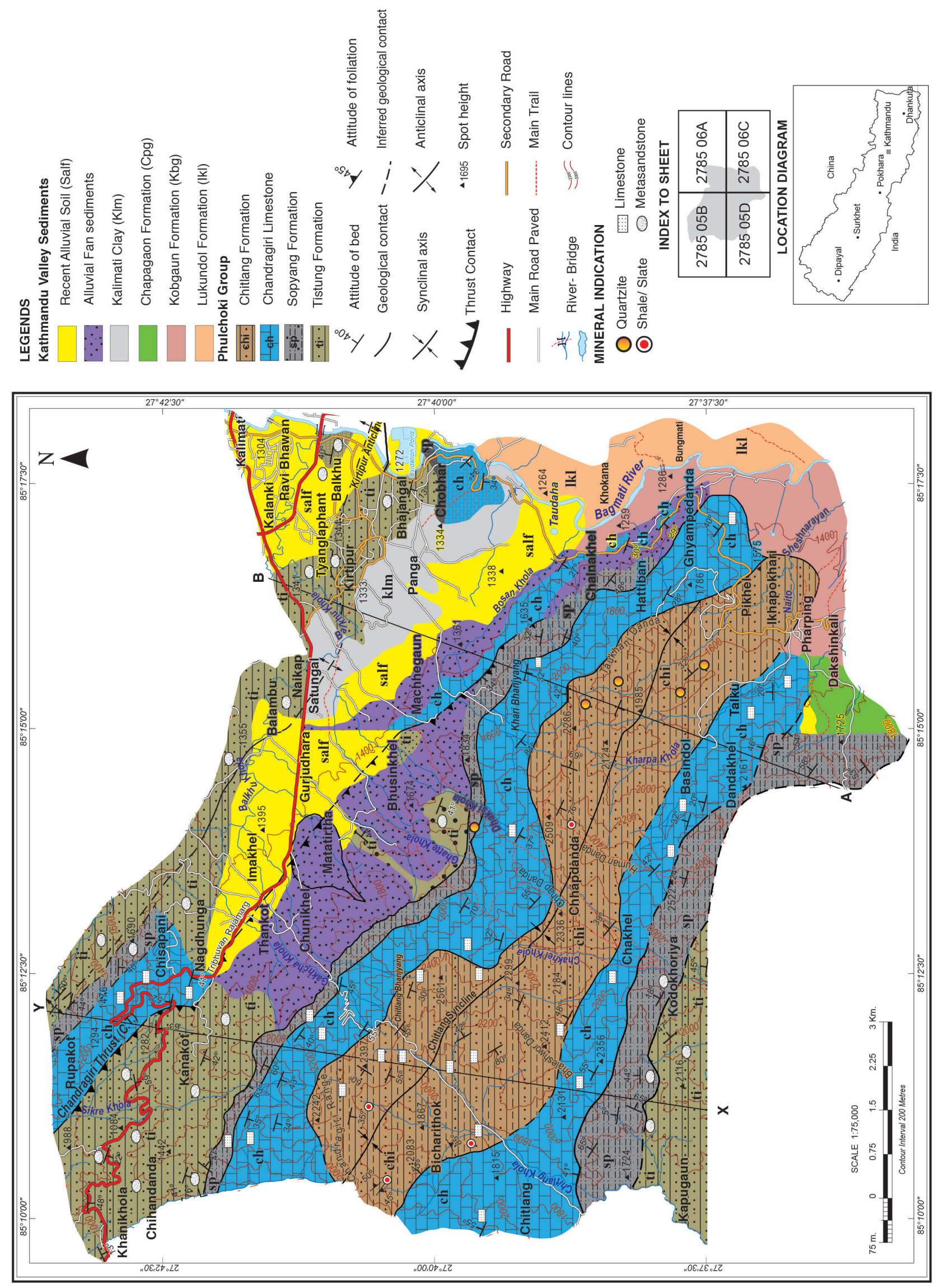

 


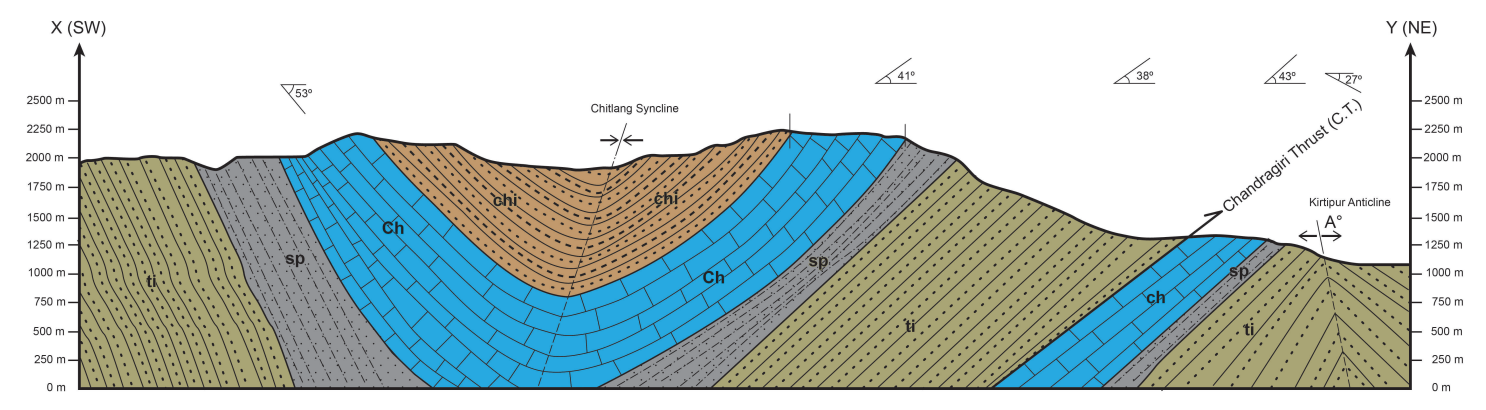

Fig. 4: Geological cross-section along Chhabugau (SW) -to Kholegau (NE)

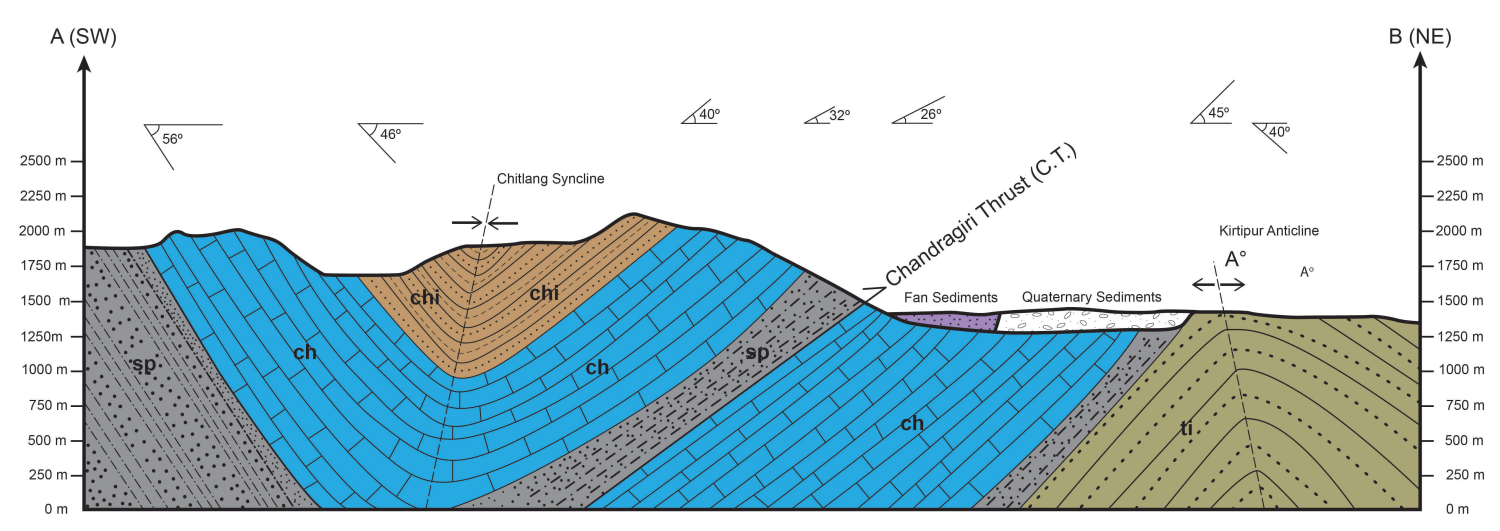

Fig. 5: Geological cross-section along Fakhel (SW) -to Naikap (NE)

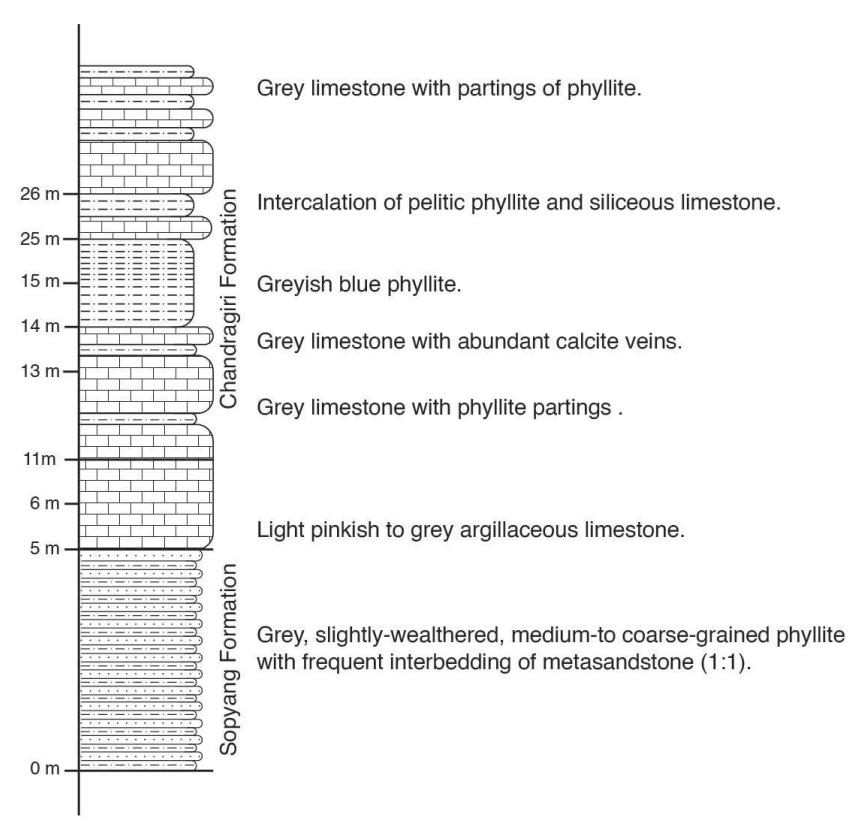

Fig. 7: A detailed columnar section of transitional contact between the Sopyang Formation and the Chandragiri Limestone about $1 \mathrm{~km}$ uphill from Godam, Thankot

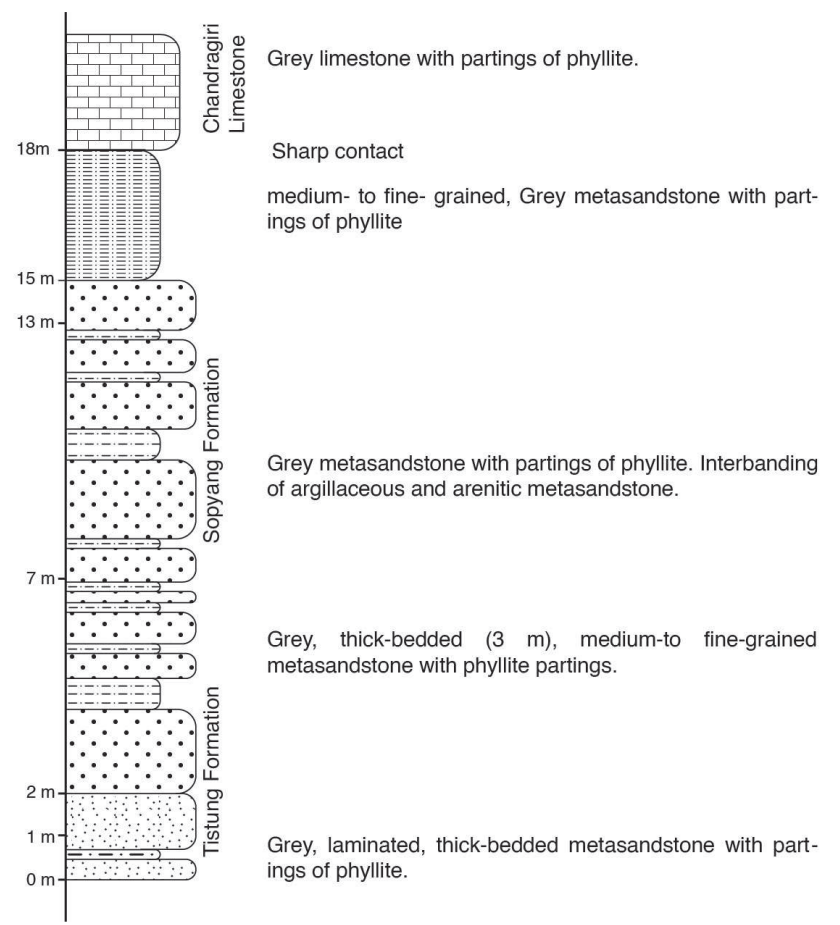

Fig. 8: A detailed columnar section of a part of the Tistung Formation, Sopyang Formation and Chandragiri Limestone at Chovar 


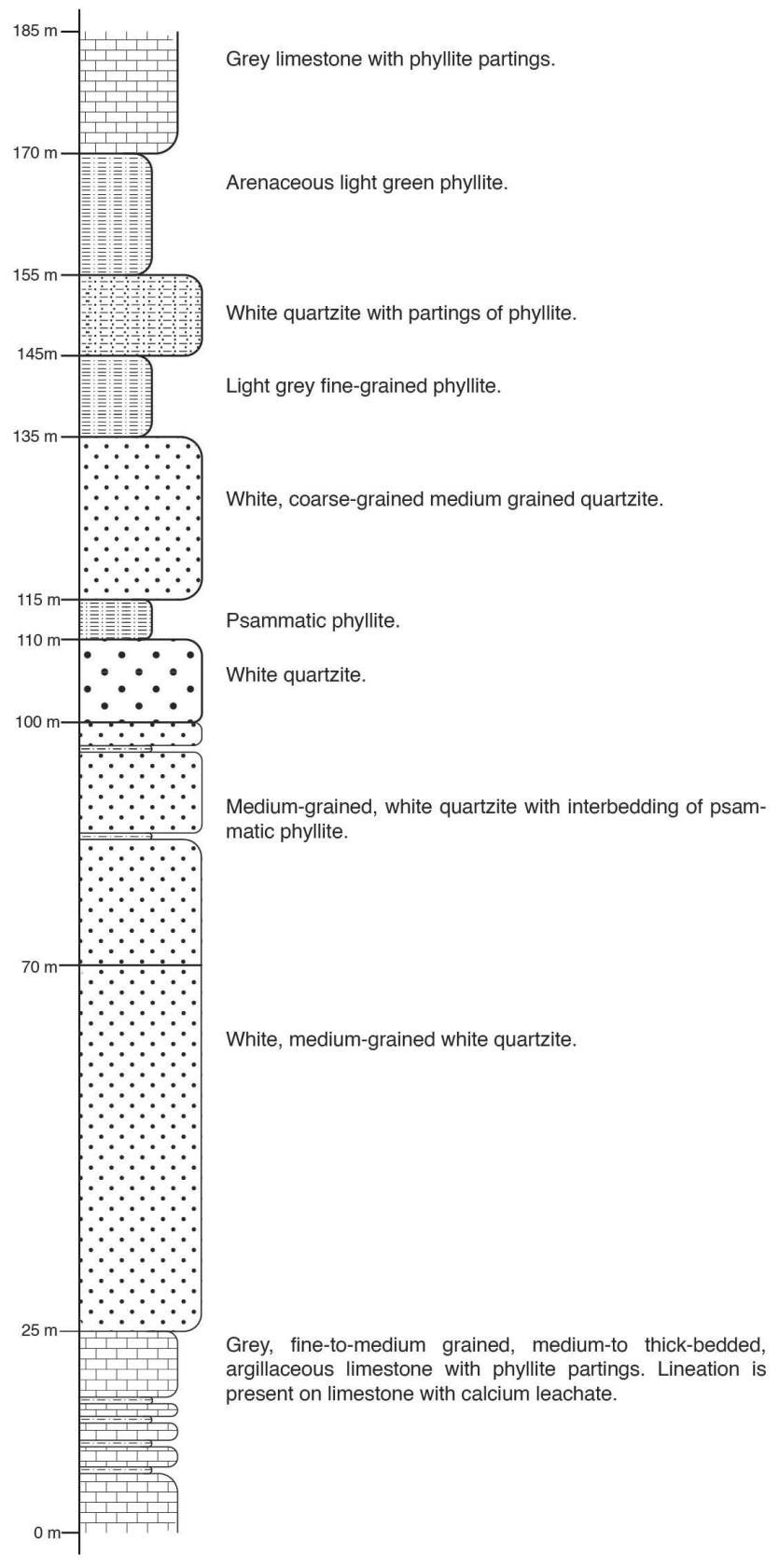

Fig. 9: A detailed columnar section showing quartzite band on the Chandragiri Limestone near Deurali, Makwanpur (way to Chandragiri temple).

\section{GEOLOGICAL STRUCTURES}

The study area is a part of a fold-and-thrust belt exhibiting a number of regional, local as well as small-scale secondary geological structures. Sedimentary structures like bedding, lamination, cross bedding (Fig. 11) and ripple marks were observed in the study area. In the Chandragiri Limestone the sharp crest of the oscillation ripple (Fig. 12) point in same direction to that of the dip direction of the beds, indicating the

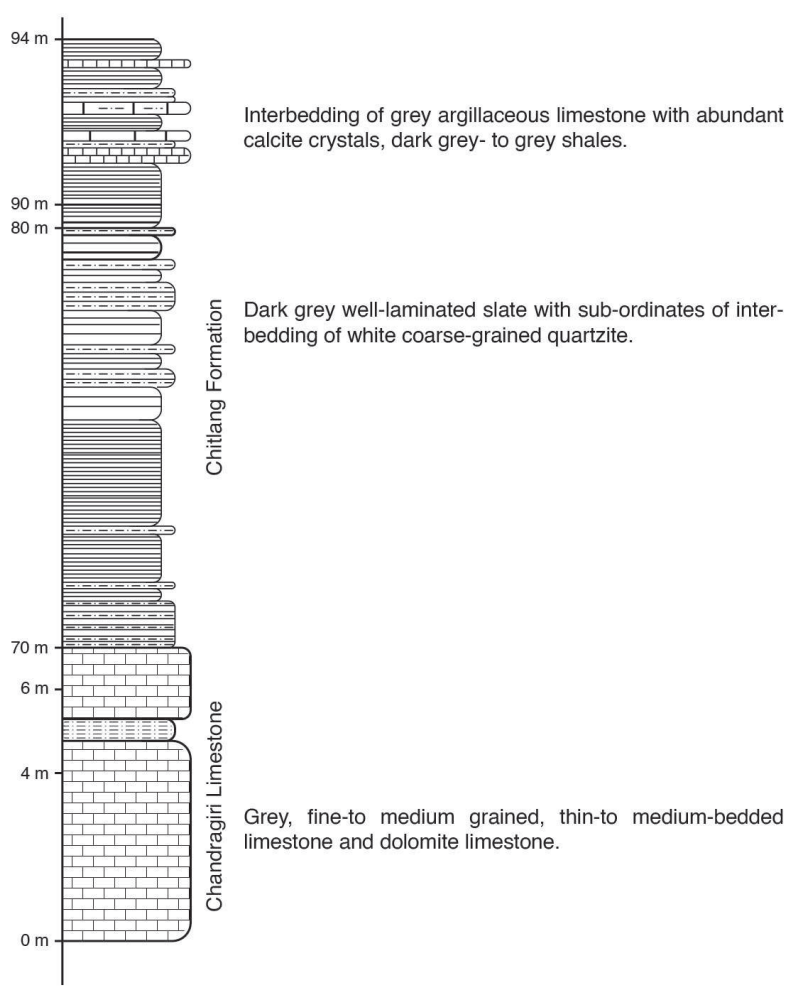

Fig. 10: A detailed columnar section of part of the Chandragiri Limestone and the Chitlang Formation about 2 km downhill from the Chitlang Bhanjyang

beds are in normal stratigraphic order. There are abundant crossbeddings observed in the metasandstones of the Tistung Formation (sites of outcrops: Balkhu Khola, Naikap, Matatirtha areas). Ripple marks are observed in the rocks of the Chandragiri Limestone and the Chitlang Formation (sites of outcrops: Godam, Chitlang Bhanjyang areas). In all areas, these sedimentary structures show the beds are stratigraphic normal (right side up).

The most important regionally present structure is the southern part of the Mahabharat Synclinorium. Both limbs of the fold were measured and plotted. The Chitlang Syncline, the Kirtipur Anticline and the Chandragiri Thrust (CT) are the prominent geological structures in the study area.

\section{Chitlang Syncline}

The Chitlang Syncline is the part of a large broad synclinorium whose core part is occupied by the rocks of the Chitlang Formation. The axis of the syncline passes through the core of the Mahabharat Synclinorium (Fig. 3 and 4). The trend and plunge of the syncline are $300^{\circ}$ and $28^{\circ}$, respectively. A contouring plot (Fig. 13) of the attitudes of the fold data shows $30^{\circ} / 32^{\circ}$ trend and plunge for northern limb, $212^{\circ} / 49^{\circ}$ trend and plunge for southern limb. The angle between two limbs is found as $81^{\circ} / 98^{\circ}$ i.e. an open fold. 


\section{Kirtipur Anticline}

The Kirtipur Anticline is also the part of a broad synclinorium. The beds and foliation around the Balkhu Khola, Naikap show the north dipping whereas the beds near Kirtipur show south dipping. The Trend/plunge of the axial plane of the Kirtipur Anticline is $102^{\circ} / 12^{\circ}$. A contouring plot of the fold data shows trend/plunge $12^{\circ} / 45^{\circ}$ for northern limb whereas, $194^{\circ} / 30^{\circ}$ for southern limb (Fig. 14). The angle between two limbs is found as $75^{\circ} / 104^{\circ}$ i.e. an open fold.

\section{Chandragiri Thrust}

The main criterion of location of the Chandragiri Thrust is repetition of stratigraphy. The thrust has brought the older rocks of the Sopyang Formation above the Chandragiri Limestone around SE part of the area. Similarly, this thrust has brought the older rocks of the Tistung Formation over the Chandragiri Limestone around NW part of the area. Other strong evidence is the geomorphological criterion i.e., a continuous alluvial fan deposit that is mapped around the lower reaches of the thrust zone. Some thrust related features like; fault breccia, abundant quartz veins and slickenside in the rocks are observed in Macchegaun section. Also, the abrupt change in altitude and extensive fan deposits in the southernmost part compared to the northernmost part of the Kathmandu Valley is another evidence for the presence of the Chandragiri Thrust. Similarly, small scale folds, joints, chatter mark, crenulations, lineation, foliation, fracture and caverns are observed in the rocks from various sections.

\section{DEFORMATION, METAMORPHISM AND MICROSTRUCTURES}

The area consists a right way up sequence of regionally metamorphosed sediments displaying a regular decrease in metamorphic grade from older to younger succession. The rocks that have undergone the metamorphism in the area are slate, phyllite, metasandstone and quartzite. Two metamorphic zones i.e., chlorite zone and biotite zone were identified. The chlorite zone (Fig. 15) is observed towards younger succession whereas, the tiny crystals of biotite are found towards the older succession.

In the area, no any evidence of the MCT related shear sense was observed. The stretching lineation (trending towards NE) was observed on the argillaceous limestone of the Chandragiri Limestone. A large numbers of brittle shear zones were observed in several outcrops that have cross-cut relation with the previously formed structures like bedding and foliation, lineation, fold axis etc. Asymmetric boudins and crenulation (Fig. 16) are frequently observed in the outcrops of the Chitlang Formation.

\section{DISCUSSIONS}

Stöcklin and Bhattarai (1977) have established the stratigraphy of the rock succession of Kathmandu area in
1:250000 scales based on photo-geology. It is the most adopted stratigraphy and geological map at present. After present study, there is some modification on the boundaries of geological units (Fig. 17) as compared to Stöcklin and Bhattarai (1977), and this made the variation in thickness of the units. The geological contacts in their map are straight while in the present study, the contacts between the geological units are found irregular. Most probably it happened due to the methodology of geological mapping and scale of mapping. At present the map was prepared by walk-over survey taking more dense routes in 1:25000. Similarly, some of the prominent geological structures like the Kirtipur Anticline and the Chandragiri Thrust are missing in their maps.

Acharya and Dhital (2006) have also studied the geology and structure of Raniban-Champadevi area and mapped the rock successions into four units adopting the names from the work of Stöcklin and Bhattarai (1977). They have shown the Kirtipur Anticline in the map. However, there is remarkable change in the geological structures with the present work. There is missing of the good exposures of the Tistung Formation and the Sopyang Formation in a large area along Matatirtha and Dhaksi sections. They have mapped the Chandragiri Limestone directly above the alluvial fan while in the present work two more units like the Tistung Formation and the Sopyang Formation have been mapped in the same area along with the Chandragiri unit. Acharya and Dhital (2006) have shown a number of anticlines and synclines in their work however, in the present study a single and large syncline (i.e the Chitlang Syncline) covers the structures of the region instead of several cycles of folds. It means the several axes of synclines they proposed are joined by a single axis of the Chitlang Syncline in the present study. Another remarkable point of discussion is the presence of the Chandragiri Fault as mentioned by Sakai (2001) and Asahi (2003). Interestingly, Stöcklin and Bhattarai (1977) as well as Acharya and Dhital (2006) have not observed the fault as mentioned by Japanese researchers Sakai (2001) and Asahi (2003). The main concern of the present study was to settle this issue and revise the previous works wherever possible. The present work has agreed with the presence of the Chandragiri Fault in the area as described by Sakai (2001) and Asahi (2003). However, from geological definition it is revised as the Chandragiri Thrust (CT) not the Chandragiri Fault, a normal fault. It is a thrust fault as the older rock succession overlies the younger units (Figs. 3 and 4). The major evidence of the presence of the Chandragiri Thrust is the repetition of stratigraphy that is justified by the along strike mapping of the units in the area. This thrust has brought the older rocks of the Sopyang Formation above the younger Chandragiri Limestone in southeastern part of the area. Also, this thrust has brought the older rocks of the Tistung Formation above the younger Chandragiri Limestone around northwestern part of the area. Other supporting evidences are the geomorphology i.e. presence of continuous alluvial fans along the lower reaches of the proposed thrust zone. In addition to these, some thrust-related features like fault breccia, slickenside, and clustering of abundant 


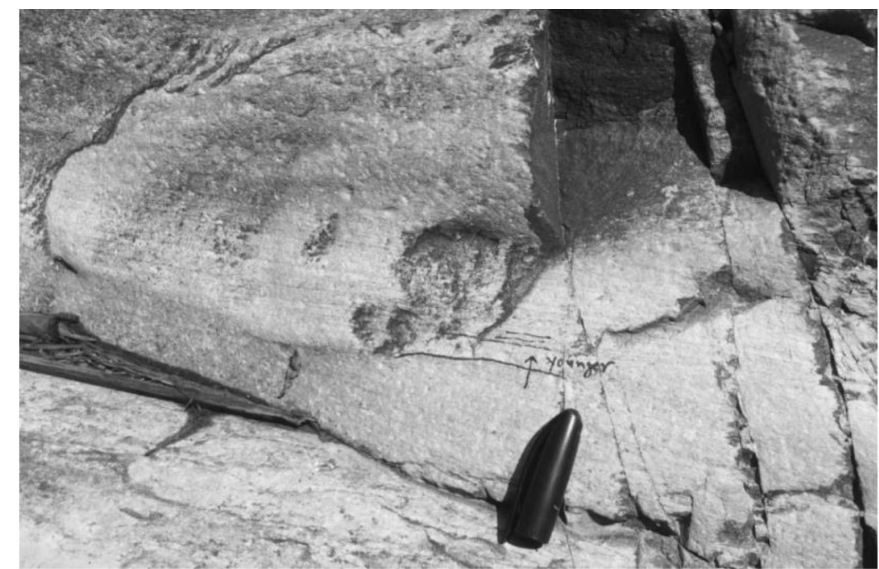

Fig. 11: Cross-bedding on metasandstone of the Tistung Formation indicating the normal stratigraphic position, as observed in the Balkhu Khola

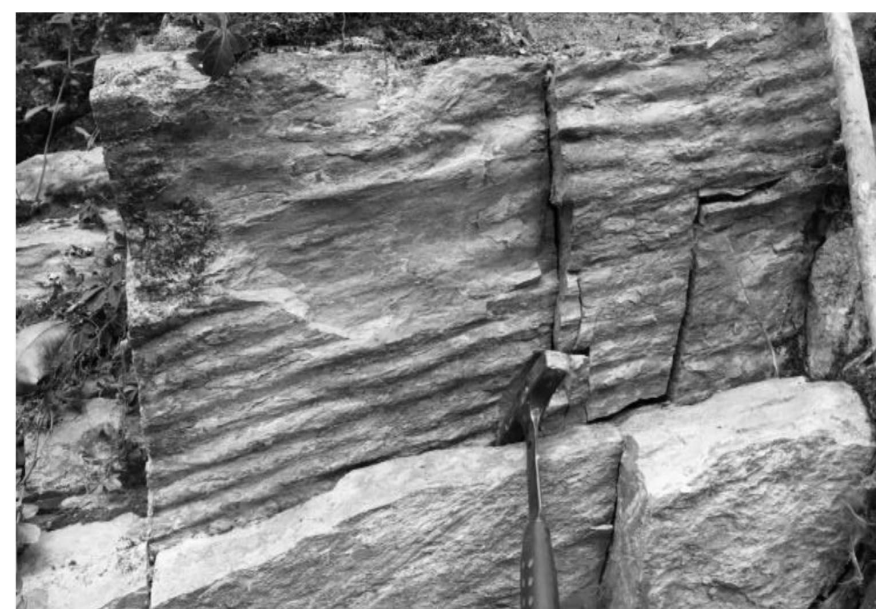

Fig. 12: Oscillation ripple marks observed on limestone of the Chandragiri Limestone about $1.5 \mathrm{~km}$ uphill from Godam, Thankot

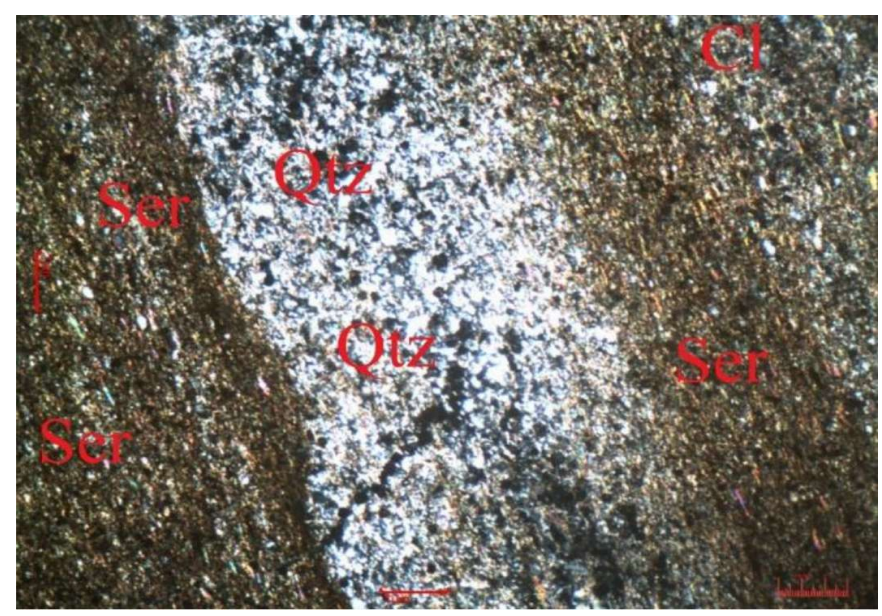

Fig. 15: Photomicrograph showing inter-layering of argillaceous and arenaceous metasandstone of the Tistung Formation, at the Khani Khola
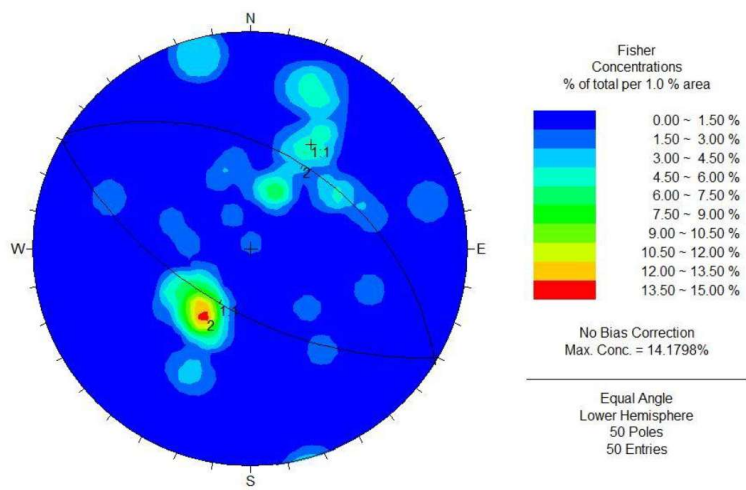

No Bias Correction
Max Conc $=14.1798 \%$

$$
\begin{aligned}
& \text { Equal Angle } \\
& \text { Lower Hemisphere } \\
& 50 \text { Poles } \\
& 50 \text { Entries }
\end{aligned}
$$

Fig. 13: Stereographic contour plot of all measured attitudes of beds/foliations in equal angle, lower hemispherical projection of the Chitlang Syncline
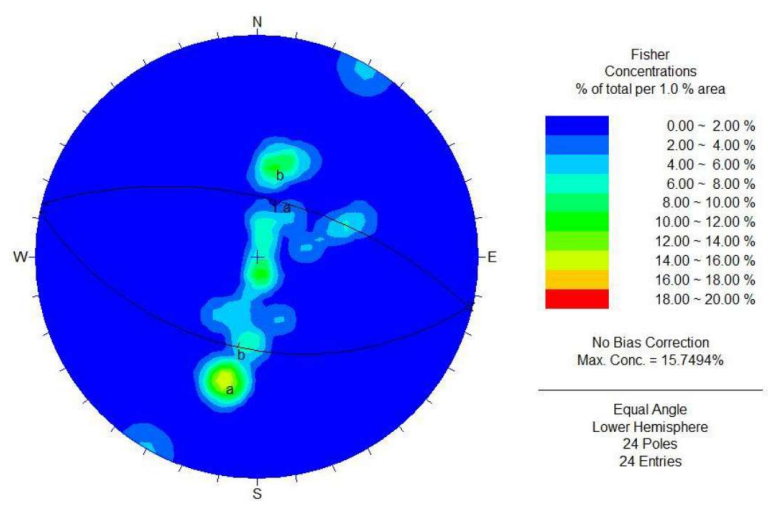

Fig. 14: Stereographic contour plot of the Kirtipur Anticline (equal angle, lower hemispherical projection)

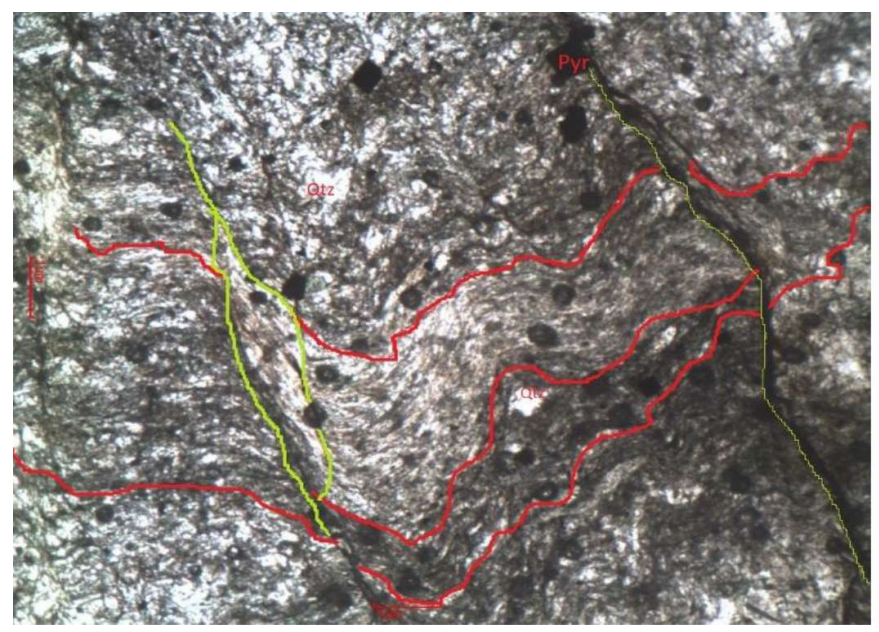

Fig. 16: Photomicrograph showing crenulations developed in slate of the Chitlang Formation 


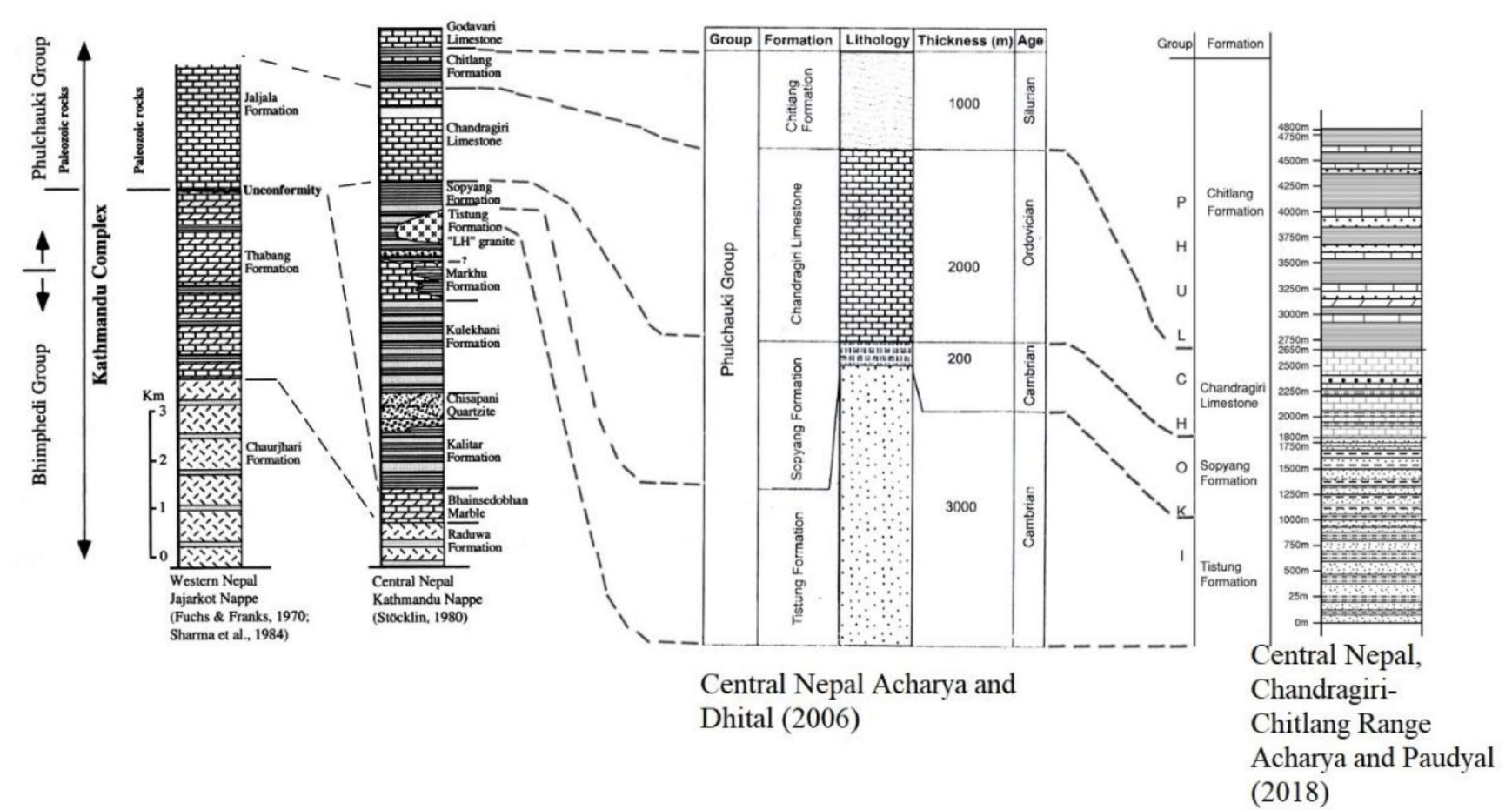

Fig. 17: Stratigraphic correlation of the study area with adjacent area

quartz veins also marks the presence of thrust in the area. Also, the abrupt change in altitude and extensive fan deposits in the southern part than the northern part of the Kathmandu Valley is the remarkable evidence to locate the Chandragiri Thrust (CT) in the area. Since, the thrust plane of the Chandragiri Thrust is itself folding; it indicates that the thrust was developed before the folding of the rocks. Another remarkable point is that the Tistung Formation is found calcareous which was not reported in the previous studies. The study area consists a right way up sequence of regionally metamorphosed sediments displaying a regular decrease in metamorphic grade from the older to the younger successions.

\section{CONCLUSIONS}

Following conclusions are drawn after the present study as:

1. The Chandragiri-Chitlang Range, southwest part of the Kathmandu Valley has developed the rocks of the upper part of the Kathmandu Nappe. The rocks of this region can be mapped under the most adopted rock units as the Tistung Formation, Sopyang Formation, Chandragiri Limestone and the Chitlang Formation from bottom to top, respectively.

2. The Tistung Formation consists of succession of metasandstone and phyllite in various proportions with occasional beds of dolomite and limestone. Remarkably, the Tistung Formation is found calcareous which was not reported in the previous studies.

3. The major regional geological structure so far mapped in the area is the Mahabharat Synclinorium. Within this mega- structure, the Chitlang Syncline, the Kirtipur Anticline and the Chandragiri Thrust are locally mapped in the area. The Chitlang Formation forms the very core of the Mahabharat Synclinorium (i.e the Chitlang Syncline). The Chandragiri Thrust is found older than the adjacent folds as the thrust plane is folded. The major evidences of the Chandragiri Thrust, as the new findings of this study, includes the stratigraphic repetition, presence of alluvial fans along the confined region and other minor thrustrelated features like fault breccia, slickenside and clustering of abundant quartz veins. Large alluvial fan deposits towards southern part and abrupt change in altitude compared to the northern part are other supporting geomorphic evidences for the presence of the Chandragiri Thrust in the region.

4. There is a normal regional metamorphism in the rocks as there is regular decrease in metamorphic grade from biotite zone to the chlorite zone from older to younger successions. Rocks are highly deformed and sheared. Two sets of foliation are found in the rocks. These represent the bedding parallel foliation and axial plane foliation as well as foliation related to the crenulation cleavages. The brittle shear zones represent the latest event of the Himalayan orogeny in the region as such structures cross-cut all the previously formed structures.

\section{ACKNOWLEDGEMENTS}

We are very grateful to Prof. Lalu Paudel, Head of the Central Department of Geology, for providing the field equipment and laboratory facilities. We are very much thankful to Prof. Dr. Ram Bahadur Sah and Dr. Naresh Kazi Tamrakar for their fruitful suggestions and comments in the manuscript. We extend thanks to Pratikshya Dhungana and Pawan Kurmar Acharya 
for their help in the field work and Miss Menuka Shrestha for supporting computer works.

\section{REFERENCES}

Acharya, K. K., 2001, Geology and structure of the PharpingRaniban area central Nepal. Unpublished M. Sc. Thesis submitted to the Central Department of Geology, Tribhuvan University, $58 \mathrm{p}$.

Acharya, K. K., and Dhital, M. R., 2006, Geology and structure of the Raniban-Champadevi area, Kathmandu Valley, central Nepal. Journal of Nepal Geological Society, v. 33, pp. $1-10$.

Arita, K., Ohta, Y., Akiba, C., and Maruo, Y., 1973, Geology of the Nepal Himalayas, Kathmandu region. InHashimoto S., Ohta Y., and Akiba, C., editions,pp. 99-145.

Asahi, K., 2003, Thankot Active Fault in the Kathmandu Valley, Nepal Himalaya. Journal of Nepal Geological Society, v. 28, pp. 1-8.

Auden, J. B., 1935, Traverses in the Himalaya. Records of the Geological Survey of India, v. 69, pp. 123-167.

Bordet, P., Cavet, J., and Pillet, J., 1959, Sur l'existence d'une faune d'âge silurien dans la région de Kathmandu (Himalaya du Népal). Paris, Académie des Sciences, Comptes Rendus, pp. 1247-1249.

Fuchs, G., and Frank, W., 1970, The geology of west Nepal between the rivers Kali Gandaki and Thulo Bheri. Jahrbuch der Geologischen Bundesanstalt,v. 18, pp. 1-103.

Gupta, V.J., and Termier, G., 1978, Lower Paleozoic Echinodermata from Chandragiri Pass, near Kathmandu, Nepal. Recent Research Geology,7 p.

Hagen, T., 1969, Report on the Geological Survey of Nepal.
Denkschr Schweizerischen Naturforschenden Gesellschaft, v. 81,185 p.

Mitchell, A.H.G., 1981, Himalayan and Transhimalayan granitic rocks in and adjacent to Nepal and their mineral potential. Journal of Nepal Geological Society, v. 1, pp. 41-52.

Paudyal, P., and Dhital, M. R., 2005, Landslide hazard and risk zonation of Thankot-Chalnakhel area Central Nepal. Journal of Nepal Geological Society, v. 31, pp. 43-50. https://doi.org/10.3126/jngs.v31i0.259

Saijo, K., Kimura, K., Komatsubara, T., and Yagi, H., 1995. Active faults in southwestern Kathmandu basin, Central Nepal. Journal of Nepal Geological Society, v. 11, pp. 217-224

Sakai, H., 2001, Stratigraphic division and sedimentary facies of the Kathmandu Basin Group, Central Nepal. Journal of Nepal Geological Society, v. 25, pp. 19-32.

Sakai, H., Yahagi, W., Fujii, R., Hayashi, T., and Upreti, B. N., 2006, Pleistocene uplift of the Himalayan frontal ranges recorded in the Kathmandu and Siwalik basins. Palaeogeography, Palaeoclimatology, Palaeoecology, v. 241, pp.16-27. https://doi.org/10.1016/j.palaeo.2006.06.017

Sharma, T., Kansakar, D. R., and Kizaki, K., 1984, Geology and tectonics of the region between Kali Gandaki and Bheri Rivers in Central west Nepal. Bulletin of the college of Science, University of Ryukyus, v. 38, pp. 57-102.

Stöcklin, J., 1980, Geology of Nepal and its regional frameJournal of Geology Society of London, London,v. 137, pp. 1-34. https://doi.org/10.1144/gsjgs.137.1.0001

Stöcklin, J., and Bhattarai, K. D., 1977, Geology of Kathmandu area and Central Mahabharat Range, Nepal Himalaya. Unpublished technical report, DMG/UNDP Mineral Exploration Project. 
